\title{
KIEDY AMATOR CHCE ZOSTAĆ SPECJALISTA. KILKA UWAG O JAKOŚCI TŁUMACZENIA PRAWNICZEGO
}

\begin{abstract}
Zarys treści: Rosnąca liczba studiów podyplomowych z zakresu przekładu tekstów specjalistycznych wydaje się dobrze zaspokajać popyt na kształcenie tego typu. Należy jednak sprawdzić, czy absolwenci takich studiów są w stanie sprostać wymaganiom rynku i oferować na nim profesjonalne usługi. Opierając się na przeprowadzonym przez siebie badaniu, autorka artykułu stara się określić, czy (lub w jakim zakresie) możliwe jest wykształcenie profesjonalnych tłumaczy tekstów specjalistycznych w ramach rocznych studiów podyplomowych z zakresu tłumaczeń ekonomiczno-prawniczych. W tym celu dokonuje oceny jakości przekładu umowy spółki dokonanego przez słuchaczy. W części teoretycznej artykułu autorka przytacza różne definicje języka prawniczego i opisuje cechy „dobrego” przekładu specjalistycznego. Natomiast w części praktycznej dokonuje analizy typowych błędów popełnionych przez badanych, starając się określić ich przyczynę oraz pokazać, jak wpłynęły na jakość tekstu docelowego. Wyciągnięte z badania wnioski mogą okazać się przydatne dla studentów, praktyków i dydaktyków przekładu oraz osób odpowiedzialnych za organizację studiów podyplomowych z zakresu tłumaczeń.
\end{abstract}

\section{Założenia teoretyczne}

\subsection{Teksty prawnicze jako rodzaj tekstów specjalistycznych}

Drzedstawiając różne typologie tekstów, badacze przekładu zaliczają teksty prawnicze do kategorii tekstów specjalistycznych (Pisarska, Tomaszkiewicz 1996, Pieńkos 2003, Jopek-Bosiacka 2006), a więc takich, których autorzy posługują się specyficzną terminologią i składnią (por. definicje języka specjalistycznego w: Lukszyn 1998, Tomaszkiewicz 2006). W rozdziale 
poświęconym tłumaczeniu prawniczemu Tomaszkiewicz podkreśla, że tłumacz tekstów prawniczych musi być „mediatorem” nie tylko między dwoma językami specjalistycznymi, ale też (często rozbieżnymi) systemami prawnymi. Badaczka zwraca również uwagę na pułapkę „wiernego” przekładu, którego od tłumacza tekstów prawniczych może oczekiwać odbiorca (Pisarska, Tomaszkiewicz 1996: 188-191). Powyższe zagadnienia szerzej opisuje Pieńkos, który dokonuje rozróżnienia między językiem prawnym a prawniczym, definiując je odpowiednio jako: „język, w którym formułowane jest prawo" oraz „język, którym posługują się prawnicy, gdy mówią o prawie, formułując swe poglądy dotyczące ważkości norm prawnych i ich klasyfikacji” (Pieńkos 2003: 103). Badacz zakłada, że zarówno teksty prawne, jak i prawnicze są przekładalne, przy czym w większości przypadków te pierwsze tłumaczone są w celach informacyjnych (tj. ich treść nie ma skutków prawnych dla odbiorcy docelowego), w związku z czym tłumacz musi uwzględnić pierwotnych odbiorców takich dokumentów oraz fakt, że powstały one w odmiennym od kultury docelowej systemie społeczno-politycznym, co wymaga od niego stosowania ekwiwalentów funkcjonalnych. Natomiast przekładając teksty „na potrzeby międzynarodowego obrotu prawnego”, tłumacz robi to w konkretnym celu i dla konkretnego odbiorcy, potwierdzając zgodność treści przekładu z zawartością oryginału. Podobnie jak Tomaszkiewicz, Pieńkos podkreśla, że konieczność stosowania ekwiwalencji formalnej w przekładzie tekstów prawniczych nie zwalnia tłumacza od zachowania norm językowych w tekście docelowym (Pieńkos 2003: 104-113 i 134139). W podobnym duchu wypowiada się Jopek-Bosiacka, która w swojej książce analizuje i porównuje cechy dyskursu prawnego w języku polskim i angielskim. Autorka zwraca uwagę na takie właściwości semantyki dyskursu prawnego jak precyzja, niedookreśloność, specjalizacja, konserwatyzm oraz złożoność, które wyróżniają go spośród pozostałych języków specjalistycznych (Jopek-Bosiacka: 16-86).

Badacze przekładu sa zgodni co do tego, że tłumaczenie dokumentów prawnych i prawniczych podlega tym samym operacjom przekładowym, co tłumaczenie pozostałych rodzajów tekstów. Zatem istotą poprawnego przekładu jest właściwa interpretacja treści oryginału, która w przypadku tekstów prawnych i prawniczych jest możliwa tylko wtedy, gdy tłumacz dysponuje odpowiednią wiedzą specjalistyczną. Dzięki niej jest w stanie dokonać dewerbalizacji tekstu źródłowego i obrać strategie, które - wraz z biegłą znajomością języka ojczystego i obcego oraz wysoką kompetencją tłumaczeniową - pozwolą mu na jego reekspresję w języku docelowym (Pisarska, Tomaszkiewicz 1996: 188-191, Pieńkos 2003: 104-106). Jopek-Bosiacka podkreśla, że „interpretowanie prawa nie jest wyłącznie procesem dekodowania”, gdyż najważ- 
niejsza jest „wykładnia językowa, uwzględniająca rolę kontekstu prawnego" (2006: 11). Tłumacz tekstów prawniczych musi również pamiętać o tym, że dokonany przez niego przekład będzie pociągał za sobą skutki prawne, dlatego nie może zaniedbać etapu redakcji tekstu, podczas którego powinien sprawdzić, czy zastosował w tekście docelowym odpowiednią ekwiwalencję tekstowo-normatywną.

\subsection{Ocena jakości przekładu tekstów specjalistycznych}

Mimo że kryteria oceny jakości przekładu są nieustannie (re)definiowane, do czynników wpływających na jakość przekładu - w tym specjalistycznego - należy zaliczyć rodzaj i poziom trudności tekstu źródłowego, znajomość języka źródłowego i docelowego przez tłumacza, jego wiedzę, kompetencję tłumaczeniową, stosowane przez niego strategie przekładowe czy posiadane narzędzia pracy. Z tego samego powodu zasady oceniania przekładu tekstów specjalistycznych są podobne do kryteriów stosowanych do oceny tłumaczenia tekstów niefachowych. Jednocześnie należy pamiętać, że ocena jakości przekładu zależy od opinii osoby oceniającej dany tekst i zastosowanych przez nią kryteriów, w związku z czym oceny jednego tłumaczenia dokonane przez różne osoby mogą się od siebie różnić. Traktuje o tym artykuł Schäffner (1998), która poddaje krytyce lingwistyczną, pragmatyczną i funkcjonalną metodę oceny jakości przekładu. Pierwsza polega na konfrontacji zgodności tekstu docelowego z tekstem źródłowym, zgodnie z drugą „dobry” przekład zależy od typologicznych właściwości oryginału, natomiast zwolennicy trzeciej teorii oceniają jakość przetłumaczonego tekstu w zależności od tego, czy jest on zgodny z celem przekładu.

Dla praktyków przekładu o jakości tłumaczenia będzie świadczyć brak błędów lub ich występowanie w tekście docelowym. W tym miejscu warto przedstawić typologie błędów opisane przez Tomaszkiewicz (1996), Hejwowskiego (2004) i Kim (2009). Omawiając etap weryfikacji przekładu, Tomaszkiewicz dzieli najczęściej popełniane błędy na tłumaczeniowe i językowe (1996: 143-154). Pierwszy rodzaj błędów wynika z zastosowania złej metody tłumaczeniowej i obejmuje: interferencję, stosowanie niewłaściwych zapożyczeń, błędy wynikające z niezrozumienia oryginału (przez które tekst docelowy zwiera informacje fałszywe, sprzeczne lub pozbawione sensu w odniesieniu do tekstu źródłowego) oraz brak zastosowania zasady kompensacji (podanie zbyt małej lub dużej ilości informacji, nieuzasadniony wolny przekład). Do drugiej kategorii błędów Tomaszkiewicz zalicza: 
wieloznaczność, barbaryzmy i charabię (bełkot). Hejwowski wyróżnia cztery kategorie błędów tłumaczeniowych: błędy tłumaczenia syntagmatycznego, błędy mylnej interpretacji, błędy realizacji oraz błędy metatranslacyjne (2004: 124-149).

Nowatorską typologię błędów przedstawia Kim (2009: 123-153), która, opierając się na teorii lingwistyki funkcjonalnej, opracowała zorientowane na znaczenie kryteria oceny przekładu (meaning-oriented assessment). Autorka dzieli błędy na znaczące (major errors) i nieznaczące (minor errors). Znaczące błędy mają wpływ na co najmniej jeden $\mathrm{z}$ czterech aspektów znaczeniowych: wypływający z doświadczenia (experiential), logiczny (logical), interpersonalny (interpersonal) oraz tekstowy (textual) i przekładają się na dokładność przekazu oraz naturalność języka tekstu docelowego. Błędy nieznaczące, do których można zaliczyć błędy ortograficzne, nie mają wpływu na sens przekładu. Zależnie od rodzaju i wagi błędu sprawdzający może odjąć za niego od 0,5 do 3 punktów. Przekład uważa się za poprawny, gdy liczba punktów ujemnych nie przekracza 45. Zdaniem Kim zaletą proponowanego przez nią schematu oceny translacji jest to, że pomaga adeptom tłumaczenia zastosować teoretyczne aspekty przekładu w praktyce, systematycznie analizować stosowane strategie tłumaczeniowe i popełniane błędy pod kątem ich wpływu na różne aspekty znaczenia tekstu docelowego, opracowywać strategie unikania błędów oraz rozwijać autonomię uczenia się.

Biorąc pod uwagę rosnącą liczbę studiów podyplomowych z zakresu przekładu specjalistycznego, należy zastanowić się, czy kształcenie tłumaczy tekstów fachowych polegające na zaznajamianiu ich z teorią i praktyką przekładu, rozwijaniu ich kompetencji tłumaczeniowej oraz przekazaniu im odpowiedniego zasobu wiedzy z danej dziedziny wystarczy do wykształcenia profesjonalistów. Mimo że taka hipoteza jest dużym uproszczeniem istoty dydaktyki przekładu, w tym przekładu specjalistycznego, opisy zamieszczone na stronach internetowych uczelni oferujących coraz liczniejsze i różnorodne studia podyplomowe z zakresu tłumaczeń wyraźnie wskazują na to, że ich celem jest wykształcenie profesjonalnych tłumaczy, którzy będą w stanie sprostać wymaganiom rynku i oferować na nim usługi najlepszej jakości. Celem niniejszego artykułu jest przedstawienie wyników eksperymentu przeprowadzonego wśród słuchaczy studiów podyplomowych z zakresu tłumaczeń ekonomiczno-prawniczych oraz określenie, czy (i na ile) przekład dokonany przez takie osoby może zostać uznany za „dobry", a tym samym czy można je uznać za profesjonalnych tłumaczy. Ocena jakości tekstów docelowych została oparta na typologii błędów opisanej przez Tomaszkiewicz (1996). 


\section{Opis badania}

Wspomniany eksperyment polegał na przełożeniu umowy spółki angielskiej (memorandum of association) na język polski. Tłumaczami byli słuchacze studiów podyplomowych z zakresu tłumaczeń prowadzonych na uniwersytecie (20 osób) oraz w prywatnej szkole wyższej (40 osób). Większość badanych to absolwenci filologii angielskiej (po studiach licencjackich lub magisterskich), pozostałe osoby, z których przeważająca część zdała egzaminy językowe (FCE, CAE, CPE), ukończyły inne kierunki studiów (np. prawo, ekonomię, inne filologie). Część badanych zajmowała lub zajmuje się przekładem. Ze względu na to, że motywacja tłumacza może mieć znaczący wpływ na jakość przekładanego tekstu, warto zauważyć, że badani podjęli studia podyplomowe, aby przygotować się do egzaminu dla tłumaczy przysięgłych, uzupełnić wykształcenie, rozwinąć sprawności językowe lub spełnić wymagania pracodawcy.

Badani mogli przetłumaczyć część umowy spółki (około 1800 znaków) z języka polskiego na angielski lub z języka angielskiego na polski. Pierwszy tekst pochodził z Internetu (http://www.monitorprawniczy.pl), natomiast drugi został zaczerpnięty z podręcznika Legal English autorstwa Małgorzaty Jakubaszek (2004, s. 103-104). Słuchacze ćwiczyli przekład podobnych tekstów podczas zajęć, w związku z czym byli zaznajomieni z ich makro- i mikrostrukturą oraz z używanym w nich słownictwem specjalistycznym. Ponadto w trakcie studiów badani poznali zasady i techniki przekładu, a także mieli wykłady z prawa polskiego i anglosaskiego, co dało im szanse na zdobycie fachowej wiedzy oraz miało zachęcić ich do jej systematycznego pogłębiania. Badani mieli dwa miesiące na wykonanie zadania, dzięki czemu mogli swobodnie konsultować się z różnymi źródłami i ekspertami oraz starannie dokonać przekładu. Zadanie nie było obowiązkowe i zostało wykonane przez 34 z 60 słuchaczy. Większość osób (29) zdecydowała się na przetłumaczenie umowy z języka angielskiego na polski, najprawdopodobniej dlatego, że czuła się pewniej tłumacząc tekst na język ojczysty, który teoretycznie zna lepiej niż język obcy. Ze względu na to, że umowę z języka polskiego na angielski przetłumaczyło tylko pięć osób, nie będzie ona przedmiotem rozważań w niniejszym artykule.

\section{Charakterystyka błędów popełnionych przez badanych}

Odpowiedzialność tłumacza za jakość tekstu docelowego jest niepodważalna. To on w pierwszej kolejności ocenia swój przekład i, uznawszy go za pełnowartościowy, przekazuje odbiorcy. Analizując teksty dostarczone przez ba- 
danych, można spostrzec, że ich własna ocena przetłumaczonych przez nich tekstów odbiega od oceny odbiorcy (nauczyciela). Taka rozbieżność może wynikać z faktu, że wiedza i umiejętności słuchaczy nie pozwoliły im przełożyć tekstu lepiej, lub z nastawienia badanych, którzy potraktowali zadanie jako formę testu sprawdzającego ich umiejętności językowe, nie zaś przekład per se, oczekując, że nauczyciel skoryguje popełnione przez nich błędy, dzięki czemu będą mogli pogłębić swoją wiedzę (Klaudy 1995). Oparta na typologii błędów przedstawionej przez Tomaszkiewicz (1996) analiza przekładów dokonanych przez badanych wykazała, że najczęściej popełniane przez nich błędy tłumaczeniowe to: hipertłumaczenie, interferencja, niewłaściwy dobór odpowiedników oraz wypaczanie sensu poszczególnych słów. Słuchaczom nie udało się uniknąć również błędów językowych, głównie solecyzmów i charabii. W dalszej części artykułu przyjrzymy się bliżej wymienionym błędom i postaramy się dociec, co było przyczyną ich pojawienia się w tekście docelowym.

\subsection{Błędy tłumaczeniowe}

\subsubsection{Hipertłumaczenie}

Przykładem hipertłumaczenia jest przekład firmy spółki „Joseph Sharp (Vegetables) Limited”, który według jednego z tłumaczy powinien brzmieć: „Joseph Sharp (Vegetables) Limited Spółka z odpowiedzialnością ograniczoną do wartości kapitału nominalnego". Mimo że takie tłumaczenie dobrze oddaje znaczenie słowa limited, dodanie takiego rozszerzenia $w$ tytule tekstu jest błędne. Podobnie jak formy prawne polskich spółek, oznaczenie spółki angielskiej (limited) jest częścią jej firmy i nie powinno być tłumaczone w nagłówku umowy. Lepszym rozwiązaniem byłoby zastosowanie dubletu tłumaczeniowego w treści dokumentu, gdy nazwa spółki zostaje wymieniona po raz pierwszy (Jopek-Bosiacka 2006: 93). W omawianym przypadku poziom wiedzy oraz kompetencja tłumaczeniowa badanego nie pozwoliły mu na poprawne zastosowanie ekwiwalencji tekstowo-normatywnej.

\subsubsection{Interferencja}

Mimo że jako osoby na co dzień pracujące z językiem słuchacze powinni zdawać sobie sprawę z wpływu języka angielskiego na współczesną polszczyznę, 
nie udało im się rozpoznać kilku „fałszywych przyjaciół”. Przykładami interferencji z języka angielskiego są następujące tłumaczenia: lease - „leasing”, interest - „interes” oraz packed food - „pakowana” lub „opakowana żywność". Tłumacze, którzy zdecydowali się zastosować przytoczone wyżej odpowiedniki, dali się zwieść „fałszywym przyjaciołom” najprawdopodobniej w przekonaniu, że stosują powszechnie przyjęte anglicyzmy. W pierwszym przypadku tłumacz ograniczył znaczenie czasownika lease („dzierżawić”) do funkcjonującego we współczesnej polszczyźnie zapożyczenia, gdyż najwyraźniej, niezależnie od formy gramatycznej, uznał je za jedyny sens tego słowa i nie sprawdził jego znaczenia $\mathrm{w}$ słowniku. Podobnie jest $\mathrm{z}$ przekładem rzeczownika interest, który w omawianej umowie nie został użyty w znaczeniu 'interes', a 'udział. Powyższe przykłady są również dowodem braku wiedzy specjalistycznej tłumaczy oraz błędnej interpretacji (i reinrepretacji) tekstu. W przypadku packed food zastosowanie odpowiedników „pakowana” i „opakowana żywność" wykazuje, że tłumacze niedostatecznie znają mowę ojczystą, w związku z czym nie stosują polskiego ekwiwalentu, którym jest „żywność paczkowana”.

\subsubsection{Dobór złych odpowiedników}

Kolejnym błędem tłumaczeniowym popełnianym przez badanych jest dobór złych odpowiedników, którego przykładami są: memorandum of association - „statut założycielski” lub „umowa zrzeszenia spółki akcyjnej”; uncalled capital - „kapitał, którego spółka jeszcze nie zażądała”; to take on property „podejmowanie się nieruchomości”; to develop such property - „rozwój takiej nieruchomości”; to join with any person or firm - "przyłączenie/dołączenie/ /łączenie się z inną osobą lub firmą”; plants - „rośliny”; works - „roboty, prace budowlane". Niewłaściwe, a wręcz niewystępujące w języku polskim ekwiwalenty sprawiają, że znaczenie tekstu źródłowego w języku docelowym staje się niejasne i wbrew pozorom (lub przekonaniu badanych) nie są przykładem tłumaczenia nacechowanego obcością. W przypadku memorandum of association tłumacz pomylił pojęcia „akt założycielski” i „statut spółki”, tym samym tworząc sformułowanie „statut założycielski”, które w polskim języku prawniczym istnieje, ale odnosi się do stowarzyszeń, nie zaś do spółek. Warto zauważyć, że w omawianym kontekście właściwym przekładem memorandum of association jest „akt założycielski spółki” lub „umowa spółki”, gdyż oryginał jest dokumentem określającym tożsamość spółki i jej relacje ze światem zewnętrznym (artykuł 157 k.s.h., Jopek-Bosiacka 2006: 122-123). „Kapitał, któ- 
rego spółka jeszcze nie zażądała" (ang. uncalled capital) jest przykładem przekładu opisowego, którego zastosowanie w tym przypadku jest błędne, gdyż w polskim języku prawniczym występują pojęcia „kapitał niewniesiony” lub „nieopłacony”. Podobnie jak w przypadku wyżej wymienionych kategorii błędów, tym razem również można założyć, że badani dokonali złej interpretacji tekstu źródłowego, ponieważ żadnemu z nich nie udało się wydobyć z niego „konkretnej rzeczywistości prawnej” (Pieńkos 2003: 297).

Zwrot to take on property powinien być przetłumaczony jako "przyjmować majątek” (ewentualnie „przyjmować nieruchomość”), nie zaś „podejmować się nieruchomości", gdyż takie sformułowanie nie ma w języku polskim najmniejszego sensu. Tłumacz, który frazę to develop such property przełożył jako „rozwój nieruchomości”, ograniczył się do zastosowania podstawowego znaczenia czasownika to develop, nie bacząc na to, że w omawianym kontekście jego sens to 'rozbudowywać. Kuriozalnym przykładem doboru złego odpowiednika jest przetłumaczenie rzeczownika plant jako „rośliny”. Najprawdopodobniej tłumacza zmylił przedmiot działalności spółki (m.in. sprzedaż warzyw i owoców), jednak z tekstu oryginalnego jasno wynika, że w tym przypadku właściwym ekwiwalentem są „urządzenia”. Podobnie jest $\mathrm{z}$ rzeczownikiem works, który oznacza 'zakłady przemysłowe'. Omówione wyżej błędy dowodzą, że badani polegają na własnych zasobach leksykalnych (lexical preknowledge), w konsekwencji czego słowniki w celach reproduktywnych stosują w ograniczonym zakresie. Potwierdza to tezę Hulstijna, który w swoim badaniu dowiódł, że na pewnym etapie znajomości języka obcego użytkownicy korzystają ze słownika głównie po to, by sprawdzić znaczenie słów, które ich zdaniem są istotne dla zrozumienia tekstu (Hulstijn 1993: 142-146). Podobne obserwacje poczyniły Atkins i Varantola, konstatując, że przekładając tekst na język ojczysty, badani tłumacze używają słowników, ponieważ nie znają znaczenia słowa w języku obcym, szukają ekwiwalentu we własnym języku lub chcą utwierdzić się w przekonaniu, że znają sens danego odpowiednika (1997). Cele i strategie korzystania ze słowników przez użytkowników polskich szerzej opisuje Lew $(2002,2004)$.

\subsubsection{Zmiana sensu}

Przekładając omawianą umowę spółki, słuchacze często zmieniali jej sens. Przykładami zastosowania fałszywego sensu są tłumaczenia: food - ,jedzenie” (zamiast „żywność”), to remove or replace any buidlings - „burzenie lub zastępowanie każdego budynku” (zamiast „wyburzać wszelkie budynki i za- 
stępować je nowymi”) czy to pay all or any of the preliminary expenses of the company - „płacenie całościowych lub częściowych kosztów początkowych naszej spółki” (zamiast „pokryć wszelkie koszty związane z założeniem spółki”). Tłumaczom zdarzało się również przedstawić sens przeciwny do znaczenia oryginału. Fraza The objects for which the company is established are: (i) To carry on business as wholesalers... została przełożona jako „Celem założenia spółki jest: (i) Prowadzenie działalności handlowej przez hurtowników...", mimo że oznacza „Spółka zostaje zawiązana w celu prowadzenia hurtowej sprzedaży..." Podobnie jest $\mathrm{z}$ fragmentem to do all such things as in the discretion of the directors, który powinien zostać przetłumaczony jako „wykonywać powyższe czynności, które zarząd spółki uzna za...”, nie zaś „Wszystkie te przedsięwzięcia wykonywane są wyłącznie wedle własnego uznania członków zarządu spółki”. Najbardziej rażącym przykładem zmiany sensu tekstu źródłowego jest nonsens, który uniemożliwia zrozumienie oryginału. Zdarzyło się tak w przypadku sformułowania to buy, take on [...] or otherwise acquire any real or personal property or any interest in such property, które zostało przełożone jako „Kupno, zatrudnianie [...] lub w przeciwnym wypadku nabywanie jakiejkolwiek nieruchomości lub ruchomości lub jakiekolwiek zainteresowania takową własnością, mimo że znaczy „nabywać w drodze kupna, przyjmować [...] lub w inny sposób nabywać wszelki majątek ruchomy i nieruchomy lub udziały w takim majątku". Powyższe przykłady dowodzą, że badani zaniedbali etap weryfikacji tekstu docelowego, podczas którego powinni byli porównać jego treść $\mathrm{z}$ zawartością oryginału, co pozwoliłoby im zauważyć błędy związane z wypaczeniem sensu tekstu źródłowego. Nie można również wykluczyć, że słaba kompetencja tłumaczeniowa słuchaczy nie pozwoliła im przełożyć umowy w inny sposób.

\subsection{Błędy językowe}

\subsubsection{Solecyzmy i charabie}

Poza błędami tłumaczeniowymi słuchacze popełnili również wiele innych błędów językowych, takich jak solecyzmy i charabie. Przykładem przeniesienia składni języka oryginału do tekstu docelowego jest fragment To carry on any business [...] which may be deemed by them to be capable directly or indirectly of enhancing the value or rendering profitable any of the property of the company, który przetłumaczono jako „Prowadzenie jakiejkolwiek działalności gospodarczej [...], która przez członków zarządu zostanie uznana 
za zdolną do zwiększenia w sposób pośredni lub bezpośredni wartości spółki lub uczynienia mienia spółki dochodowym". Natomiast charabia pojawiła się w poniższym przekładzie „Prowadzenie jakichkolwiek interesów, które w opinii dyrektorów przedsiębiorstwa mogą być zdatne do bycia płynnie przeprowadzonych w połączeniu $z$ lub jako pomocnicze do wyżej wymienionego interesu lub interesów, lub które mogą być uznane prze nich jako zdolne do bezpośredniego lub pośredniego zwiększenia wartości lub uczynienie zyskownym każdej własności firmy lub wspieranie wszystkich jej obiektów". Zrozumienie tak bełkotliwego tekstu bez ponownego przekładu oryginału jest niemożliwe. Podobnie jak w przypadku błędów związanych ze zmianą sensu tekstu źródłowego, powyższe przykłady świadczą o zaniedbaniu etapu weryfikacji tekstu.

\subsubsection{Pozostałe błędy językowe}

Mimo że słuchacze są rodzimymi użytkownikami języka polskiego, przełożone przez nich teksty nie są wolne od podstawowych błędów gramatycznych, leksykalnych, a nawet ortograficznych. Najczęściej występującym błędem gramatycznym jest niewłaściwa fleksja, która ujawniła się w przekładzie następujących partii tekstu: The objects for which the company is established are - „Cele powstanie spółki”, to develop such property of the company or of furthering of its objects - „zagospodarowanie takiej własności, albo w inny sposób przekształcenia go na korzyść spółki", to charge [...] assets of the company - „obciążanie [...] aktyw spółki”, czy to buy - „zakupywać”. Popełnione przez słuchaczy błędy gramatyczne mają wpływ na stylistykę tekstu, czego przykładem mogą być tłumaczenia typu may be [...] conducive to the attainment of the above objects or any of them - „sprzyjać osiągnięciu powyższych celów lub niektórych $\mathrm{z}$ nich" czy The share capital of the company is $\equiv 100 \mathrm{di}$ vided into one hundred shares of $€ 1$ each - „Kapitał zakładowy spółki wynosi 100.000,00 funtów i dzieli się na sto udziałów po 1 funt każdy”.

Podobnie jest $\mathrm{z}$ błędami leksykalnymi. Przełożenie directors jako „kierownictwo", to be conducive to the attainment of the above objects [of the company] jako „wspierać cele spółki” czy sellers of vegetables jako „zbywcy warzyw" znacznie obniża jakość tekstu docelowego, zwłaszcza że powyższe zwroty nie powinny sprawiać trudności nawet niedoświadczonym tłumaczom. Słuchacze zdali się zapomnieć, że directors to 'zarząd spółki', sellers of vegetables to po prostu 'sprzedawcy warzyw', a to be conducive to the attainment of the above objects [of the company] można przetłumaczyć jako „będzie 
sprzyjać osiągnięciu celów [spółki]”. Jednymi z najbardziej rażących błędów popełnionych przez tłumaczy są błędy ortograficzne, do których zalicza się zapisywanie słowa „eksport” za pomocą litery „x”, występującej w polskiej pisowni w ograniczonym zakresie (Nowy słownik ortograficzny $P W N z$ zasadami pisowni i interpunkcji 1997: XVII) czy używanie zamiast akronimu GBP symbolu „£” w celu oznaczenia brytyjskiej waluty. Można założyć, że wyniknęly one z zastosowania zasady „kopiuj i wklej”, w tym przypadku polegającej na przeniesieniu tekstu oryginalnego do przekładu. Mimo że powyższa zasada może ułatwić pracę nad tekstem (nie trzeba co chwilę zerkać na wydruk oryginału), nie zwalnia ona tłumacza z obowiązku redakcji przekładu. Przytoczone wyżej błędy świadczą o niedbałości tłumaczy o jakość przekładu oraz o zaniedbaniu etapu weryfikacji tekstu.

\section{Podsumowanie}

Powyższe rozważania prowadzą do następujących wniosków:

1) Liczba przedłożonych tłumaczeń wskazuje na to, że słuchacze preferują tłumaczenie na język polski. Dzieje się tak najprawdopodobniej dlatego, że wydaje się im, iż przekład tekstów na język ojczysty nastręcza mniej trudności niż tłumaczenie na język obcy. Mimo ogólnej słuszności takiego założenia, powyższe przykłady świadczą o tym, że znajomość rodzimego języka jest wśród słuchaczy niewystarczająca, by mogli stworzyć satysfakcjonujący jakościowo przekład (Kościałkowska-Okońska 2005: 120-121, 2007: 224-226). Dla nauczyciela takie spostrzeżenie oznacza, że musi regularnie przeprowadzać ćwiczenia weryfikujące poprawność stosowanej przez adeptów tłumaczenia polszczyzny, natomiast organizatorzy studiów podyplomowych z zakresu przekładu powinni zaoferować słuchaczom większą liczbę godzin zajęć z języka ojczystego.

2) Dostępność narzędzi tłumacza nie przekłada się na jakość tekstu w języku docelowym. Mimo że słuchacze mieli dużo czasu na przełożenie tekstu, w związku z czym mogli konsultować się z dowolną liczbą specjalistów oraz wykorzystać cały wachlarz tekstów paralelnych, korpusów językowych, słowników, wydawnictw encyklopedycznych i stron internetowych, $\mathrm{w}$ dostarczonych przez nich pracach nie widać efektów sięgania do tego typu źródeł. Szczególnie zastanawiająca jest nieumiejętność korzystania ze słowników - omówione przykłady dobitnie pokazują, że słuchacze najczęściej wybierają pierwszy ekwiwalent podawany przez słownik, nie bacząc na to, czy pasuje on do kontekstu wypowiedzi. Wziąwszy pod uwagę zaawanso- 
waną znajomość języka angielskiego przez badanych oraz fakt, że większość $\mathrm{z}$ nich naucza tego języka, zjawisko to można uznać wręcz za niepokojące. $\mathrm{W}$ związku z tym do zajęć z przekładu należy wprowadzić więcej ćwiczeń ze słownikami oraz porównywać błędne tłumaczenia z przykładami poprawnych przekładów.

3) Jak zauważono na początku artykułu, część słuchaczy mogła nie dopracować swoich przekładów w przekonaniu, że nauczyciel poprawi wszelkie błędy i w ten sposób zademonstruje im, jak powinien wyglądać dobry jakościowo przekład. Biorąc pod uwagę, że badani są początkującymi tłumaczami, takie założenie można uznać za słuszne. Z drugiej strony fakt bycia adeptem zawodu nie zwalnia tłumacza od należytego zastosowania poszczególnych operacji przekładowych ani od odpowiedzialności za jakość przełożonego tekstu (Pisarska, Tomaszkiewicz 1996, Pieńkos 2003, Hejwowski 2004, Jopek-Bosiacka 2006). Należy zwracać słuchaczom uwagę na to, by nie pomijali żadnego etapu tłumaczenia oraz by stosowali strategie retrospektywne w celu rozwiązywania problemów tłumaczeniowych (translation as a retrospective-prospective process, Lörscher 1991).

4) W eliminacji błędów słuchaczom może pomóc odpowiedni sposób oceniania. W tym wypadku warto rozważyć zastosowanie modelu oceny zorientowanego na znaczenie, proponowanego przez Kim (2009).

5) O ile rozszerzenie oferty edukacyjnej z zakresu tłumaczeń wychodzi naprzeciw oczekiwaniom nie tylko osób zainteresowanych wykonywaniem zawodu tłumacza, ale również badaczy, postulujących zwiększenie liczby godzin nauczania przekładu w formie ćwiczeń praktycznych, seminariów przedmiotowych, specjalizacji i/lub studiów podyplomowych (Kościałkowska-Okońska 2005), należy zauważyć, że doświadczenie zdobyte w ramach zajęć dydaktycznych nie jest gwarancją profesjonalizmu. Dlatego nauczyciele tym bardziej powinni zachęcać osoby pragnące zajmować się przekładem tekstów, w tym tekstów specjalistycznych, do zdobywania doświadczenia w praktyce (Newmark 1988), dzięki czemu będą one mogły rozwinąć swoją kompetencję tłumaczeniową, polegającą m.in. na umiejętności rozwiązywania problemów i podejmowania decyzji, nabyciu automatycznych mechanizmów i pewności siebie czy umiejętności wyboru optymalnych opcji z szeregu wariantów (Kościałkowska-Okońska 2007: 223). 


\section{Literatura}

Atkins, Sue B.T., Varantola, Krista, 1997. „Monitoring dictionary use”, [w:] International Journal of Lexicography, 10(I), s. 1-45.

Dziennik Ustaw Nr 94 poz. 1037 - Kodeks spółek handlowych.

Hejwowski, K., 2004, Kognitywno-komunikacyjna teoria przekładu, Warszawa, Wydawnictwo Naukowe PWN.

Hulstijn, J.H., 1993, „When do foreign-language readers look up the meaning of unfamiliar words? The influence of task and learner variables", Modern Language Journal, 77(2), s. 139-147.

Jakubaszek, M., 2004, Legal English, Warszawa, C.H. Beck.

Jopek-Bosiacka, A., 2006, Przekład prawny i sadowy, Warszawa, Wydawnictwo Naukowe PWN.

Kim, M., 2009, „Meaning-oriented assessment of translations: SFL and its application to formative assessment", [w:] Claudia V. Angelelli, Holly E. Jacobson (red.), Testing and Assessment in Translation and Interpreting Studies. A call for dialogue between research and practice, Amsterdam-Philadelphia, John Benjamins Publishing Company, s. 123-155.

Klaudy, K., 1995, „Quality assessment in school vs professional translation”, [w:] Cay Dollerup, Vibeke Appel (red.), Teaching Translation and Interpreting 3. New Horizons, Amsterdam-Philadelphia, John Benjamins, s. 197-204.

Kościałkowska-Okońska, E., 2005, „Kształcenie filologiczne a dydaktyzacja przekładu”, Rocznik Przekładoznawczy. Studia nad teoria, praktyka i dydaktyka przekładu, t. 1, L. Zieliński, M. Pławski (red.), Toruń, Wydawnictwo UMK, s. 115-125.

Kościałkowska-Okońska, E., 2007, „Kształtowanie kompetencji tłumaczeniowej jako wyzwanie dydaktyczne", Warsztaty Translatorskie/Workshop on Translation, IV, R. Sokoloski, H. Duda, K. Klimkowski, J. Klimek (red.), Lublin-Ottawa, Katolicki Uniwersytet Lubelski-University of Ottawa, s. 217-231.

Lew, R., 2002, „A study in the use of bilingual and monolingual dictionaries by Polish learners of English: A preliminary report", [w:] Proceedings of the Tenth EURALEX International Congress, EURALEX 2002, Copenhagen, Denmark, August 12-17, 2002, Vol. 2, A. Braasch, C. Povlsen (red.), Copenhagen, Center for Sprogteknologi, Copenhagen University, s. 759-763.

Lew, R., 2004, Which Dictionary for Whom? Receptive Use of Bilingual, Monolingual and Semi-Bilingual Dictionaries by Polish Learners of English, Poznań, Motivex. 
Lörscher, W., 1991, Translation Performance, Translation Process, and Translation Strategies. A Psycholinguistic Investigation, Tübingen, Gunter Narr Verlag.

Lukszyn, J. (red.), 1998, Tezaurus terminologii translatorycznej, Warszawa, Wydawnictwo Naukowe PWN.

Newmark, P., 1988, A Textbook of Translation, New York, Prentice Hall.

Pieńkos, J., 2003, Podstawy przekładoznawstwa. Od teorii do praktyki, Kraków, Kantor Wydawniczy Zakamycze.

Pisarska, A., Tomaszkiewicz, T., 1996, Współczesne tendencje przekładoznawcze. Podręcznik dla studentów neofilologii, Poznań, Wydawnictwo Naukowe UAM.

Polański, E. (red.), 1997, Nowy słownik ortograficzny PWN z zasadami pisowni i interpunkcji, Warszawa, Wydawnictwo Naukowe PWN.

Schäffner, Ch., 1998, „From 'Good' to 'Functionally Appropriate': Assessing Translation Quality”, [w:] Translation and Quality, Ch. Schäffner (red.), Clevedon, Multilingual Matters, s. 1-5.

Tomaszkiewicz, T., 2006, Terminologia tłumaczenia, Poznań, Wydawnictwo Naukowe UAM.

\section{When the apprentice wants to become the master. Several remarks on the quality of the translation of specialist texts}

\section{Summary}

Most students pursuing postgraduate courses in specialized translation are often convinced that they will complete them as professionals. However, should they be led to believe it is possible to train a specialist within a year or two? An analysis of translations of a memorandum of association submitted by the students of such a course taught at two universities in Torun has shown the target texts to be far from perfect. In the theoretical part of the article, the author presents various definitions of legal translation as a type of specialist translation and the features of a well-translated text, with a particular focus on the mistake typologies described by Tomaszkiewicz (1996), Hejwowski (2004), and Kim (2009). In the practical part, she uses Tomaszkiewicz's typology to analyse the translation and language mistakes made by the students. Due to wrong interpretation of the text, lack of translation competence and expert knowledge, they used interference, changed the sense of various parts of the source text, transferred the English syntax into the Polish text, and even made spelling mistakes. The last part of the article presents several remarks on how to remedy these problems. Thus, the author claims that translation teachers should encourage their students to: improve their language skills to understand a foreign text and use 
their mother tongue appropriately, learn how to use various translation tools (dictionaries, corpora, specialist literature), analyse teacher's assessment of their translations, and carefully perform all stages of the translation process (interpretation, deverbalisation, and revision), treating them as a retrospective-prospective process (Lörscher 1991). 